\title{
Source Criticism and the History of Brazilian Foreign Policy
}

\author{
Eduardo Uziel ${ }^{*}$ \\ Norma Breda dos Santos**
}

\begin{abstract}
The article deals with the historical methodology in the field of Brazilian foreign policy, based on reflections on the treatment of primary sources and the lessons of two important historians of antiquity: Moses I. Finley and Arnaldo Momigliano. Without disregarding the inherent temporal differences, it is understood that it is possible to bring contemporary and ancient history closer, as well as to establish a respectful dialogue between them. The article presents a preliminary discussion on the sources for the history of Brazilian foreign policy, followed by a series of analyses and comments on several aspects of the treatment of primary sources: a) the fragmentary nature of sources and the consequences of this; b) the predominance of discursive sources; $c$ ) the use of oral history as a supplementary source; and d) the difficulty in establishing a context for document production. Studies related to Brazilian foreign policy towards the Middle East will be used, especially the case of Brazil's controversial favourable vote on Resolution 3379 (XXX) of the United Nations General Assembly, in 1975, which equated Zionism with racism.
\end{abstract}

Keywords: foreign policy; methodology; international relations; history of Brazilian foreign policy; international history.

[L]'historien n'est pas ce nécromant que nous imaginions, évoquant lombre du passé par des procédés incantatoires. Nous ne pouvons pas atteindre le passé directement, mais seulement à travers les traces, intelligibles pour nous, qu'il a laissées derrière lui dans la mesure où ces traces ont subsisté, où nous les avons retrouvées et où nous sommes capables de les interpréter (plus que jamais il faut insister sur le so far as [...]).

- Henri-Irénée Marrou, De la connaissance historique

\footnotetext{
* Ministry of Foreign Affairs, Brasília-DF, Brazil and Université Libre de Bruxelles, Bruxelles, Belgium; uziele@gmail.com. ORCID iD 0000-0001-7624-8174.

** University of Brasília (UnB), Brasília-DF, Brazil; normabs@gmail.com. ORCID iD 0000-0002-5093-4229. 


\section{Introduction}

The purpose of this article is to stir controversy and foment debate on the study of the history of Brazilian foreign policy as part of the broader field of international relations studies. Its central contention is that there is an inadequacy in the critical use of primary sources in the construction of knowledge on the foreign relations of Brazil. Put another way, the different ethos, practices and goals of historians and political scientists result in different levels of suboptimal use of primary sources in international relations research, which may lead to somehow misleading interpretations of its historical aspects.

It is important to emphasise that the thrust of this discussion is essentially practical, i.e., it aims at highlighting certain issues that affect everyday research in international relations. Theoretical debates and philosophical questions are taken into account and referred to, as appropriate, but they are not developed at length.

As noted by Jervis (2001: 388-389), the sharp distinction once drawn between history and political science is not a given anymore, but there are noticeably different assumptions and practices that might lead to incongruences in the handling of evidence. History, resistant to quantification, normally pays more attention to the sources, thoroughly assessing their context and relevance, by means of sharp internal and external criticism (Marichal 1961; Marrou 1954: 122-128; Febvre 1992: 114-118; Carr 1990: 15-19). Political scientists are more concerned with theories and more parsimonious, which often leads to a smaller interest in the primary sources used to gain access to the underlying reality (Jervis 2001: 390-399).

As a result, coming from political science, practitioners of international relations are less than familiar with the everyday criticism of sources that is so valued among historians (Gaddis 1987, 1997; Jervis 2001; Larson 2001; Trachtenberg 2006). This is not to say that research should necessarily be guided by the sources; quite the contrary - it means that the sources' inherent qualities must be taken into account in order to ensure that they are relevant and that the conclusions are fairly accurate (Finley 1994: 63-88; Carr 1990: 29). As noted by an important diplomatic historian (Schroeder 1997: 70-73), the inadequacy in treating primary sources causes problems of different natures and degrees of seriousness, ranging from minor factual mistakes, going through the reinforcement of myths, up to a far more pernicious misunderstanding of a given historical interpretation.

The debate proposed here crosses the common boundaries dividing historians and practitioners of international relations. As argued by Wendt (1998: 106-107), rationalists and postmodernists, realists and constructivists, Marxists and reflexivists, all are interested in producing knowledge based on solid empirical research (Hobson and Lawson 2008; Cardoso 1997; Vainfas 1997). As put by Finley (1994: 10):

A historical interpretation is a complex of answers to questions. The evidence propounds no questions. The historian himself does that and he now possesses an adequate array of concepts for the construction of hypotheses and explanatory models. 
The practical contribution of history is the need to address primary sources based on clear guidelines, going further than the misleading 'method' of common sense (Bloch 1952: 35-37). So as to ignite the controversy and lead the debate, reflections by two of the foremost researchers of ancient history, Moses I. Finley (1965, 1989: 57-74, 1994: 1135, 37-62) and Arnaldo Momigliano (1950), were chosen. The choice of those historians should not be cause for surprise, but does deserve clarification.

Although from a methodological point of view there are no essential differences between the fields of ancient history and the history of Brazilian foreign policy (Bloch 1952: 33-34), an otherness exists in using the instruments of the former to deal with the latter that resonates well with the provocative purposes propounded here (Momigliano 2003: 193). In fact, in one aspect at least, the two fields have similar characteristics: they depend on primary sources which are scarce and fragmentary. In the case of ancient history, this is due to the eroding effects of time undoing the remains of ancient civilisations; as for the history of Brazilian foreign policy, the reason for the scarcity of primary sources lies mostly with the state, which, at least until recently, had been stingy and capricious to release its documents. As a result, both fields had to learn to value theoretical and methodological approaches in order to build a solid foundation of knowledge.

Finley and Momigliano were two of the most important historians in their field. Their contributions, including source criticism, still reverberate strongly. Momigliano discussed ancient historians at length and, in doing so, had a profound impact on the understanding of narrative sources, an understanding which is vital to any study of history of foreign policy. Finley was even more revolutionary in bringing to history from the social sciences the use of models to interpret evidence, a practice which can be brought back to support the study of international relations (Momigliano 1975; Brown 1988; Morris 1999; Vlassopoulos 2007: 13-67; Palmeira 2007: 89-163; Hopkins and Finley 2014: 200; Jew, Osborne and Scott 2016: 1-10).

In order to avoid an excessively broad research into the uses of sources in the practice of the history of Brazilian foreign policy, examples will be drawn from Brazil's stance towards the Middle East conflict, especially the vote on Resolution 3379 (XXX) of the UN General Assembly (UNGA1975d), which equated Zionism with racism.

No thorough review of this literature will be carried out, as it will be treated, in fact, as the primary source for this study (Cardoso 1986: 84-85). The choice of the Middle East is three-pronged and not casual. First, it is an issue in which controversy abounds and where passions run high - in such a scenario, a deeper understanding of primary sources is even more essential. Second, this highly controversial nature has led to a widespread use of official discourse - a primary source itself - as the basis for the formulation of concepts - something which is always worth questioning. Third, the focus on Resolution 3379 (UNGA 1975d) derives from prior knowledge of the authors and calls the attention to the period of the military regime in Brazil, a time when sources were particularly scarce. There is much literature on the resolution, although only a few studies spend more than a few lines on it (Góes 1978; Pinheiro 2013; Breda dos Santos 2000, 2003; Goldfeld 2004; Spektor 2006; Dávila and Lesser 2012; Caraciki 2013; Breda dos Santos and Uziel 2015). 
The article begins with a preliminary discussion on the sources for the history of Brazilian foreign policy, and is then followed by a series of analyses and comments on various aspects of the treatment of primary sources, based on concepts formulated by Finley and Momigliano: the fragmentary nature of sources and its consequences; the predominance of discursive sources and the importance attributed to individual documents; the use of oral history as a supplementary source; and the difficulty in establishing a context for document production.

\section{History, international relations and access to sources}

At least until recently, the difficulty in accessing sources for historical research has made Brazilian foreign policy similar to the study of ancient history, wherein sources are characterised by their fragmentation and incompleteness. With the 'slow, gradual and secure opening' of public files in Brazil and the 2011 Access to Information Law (LAI), this scenario could change. Even before the publication of the LAI, Penna Filho (1999: 136-137) already pointed to the existence, since re-democratisation, of the possibility of researching several Brazilian diplomatic documents, especially those prior to the 1940s - which is demonstrated by the existence of multiple studies with a documentary basis. Within the Ministry of Foreign Relations (MRE or Itamaraty) - the central, but far from only depositary of documentation relevant to the study of Brazilian foreign policy - access to only a marginal portion of the archive had been granted. Additionally, the changing rules on public access have made research unpredictable. It is possible that LAI users are surprised to receive thousands of pages of documents in response to their requests, given the amount of existing material. Nonetheless, as explained by Marrou (1954: 68), there are cases in which there are simply no sources - either because they never existed, or because they were not preserved.

Hurrell (2014: 23), in prefacing the publication of his 1986 thesis, on the 1964-1985 period, comments: 'The account of Brazil in this work was written without access to many primary sources.' Letícia Pinheiro (2013: i) also refers to a 'very limited access to sources' to carry out her 1994 doctoral thesis. In another study, Pinheiro (2002: 76-77) further regrets the scarcity of sources with regard to president Ernesto Geisel's term, especially those which required higher clearance - previously called 'secreto-exclusivo, and nowadays referred to as 'supersecreto'. Researchers substantially resent the important limitations on access to sources, and many studies on the history of Brazilian foreign policy were carried out in suboptimal conditions.

The issues of access to sources and their nature are all the more important because the history of Brazilian foreign policy has been an object of studies carried out by researchers with diverse backgrounds which include political science, international relations (wherein the field of foreign policy analysis stands out), history itself and law (Salomón and Pinheiro 2013). Each one tends to value sources in a different way. Due especially to the idiographic (Elman and Elman 2001; Levy 2001) nature of their work, historians, as highlighted by Steiner (1997: 542), 
[...] are suspicious of general theories concerning historical processes and feel considerable scepticism with regard to any attempt to reduce the relations between highly complex and inconsistent human beings to formulae and games. Yet the work of John Gaddis, Akira Iriye, Paul Kennedy and Paul Schroeder clearly shows how historians can use systemic approaches to illuminate the process of change in the history of international relations.

On the other hand, it is possible, at the risk of oversimplification, to point out that the area of international relations is characteristically nomologic, systematic and generalizing, building and testing theories. This characterisation is not made to the detriment of the theoretical-methodological stance of the researcher. On the contrary, it comes from the theoretical-methodological choice, whether it is explicit or not. These specificities result, more often than not, in recalcitrant conversations between the areas of history and international relations, especially when it comes to positivistic historians and rationalistic international relations researchers. A greater willingness to exchange methods and experiences can be seen between non-traditional historians and those researchers who study international relations from the reflexivistic point of view, given that they understand that 'the truth' is intersubjectively built, meaning that interpretations are still historical products (Towbridge 1972; Steiner 1997; Viggezzi 2000; Elman and Elman 2001; Hobson and Lawson 2008; Buzan and Lawson 2016; Owens 2016).

The search for causal regularities and theoretical relevance ends up paying limited attention to the peculiarities of the sources. This phenomenon is not exclusive to studies in international relations, nor to the Brazilian intellectual production in the field. In the words of Deese (2008: 8),

[...] work that tends to sacrifice historical accuracy on the altar of advancing theory was not weighted equally with theoretical explanations that was careful to get the history right. In other words, some scholars are clearly more committed to their theory than to the empirical cases or data.

The aspects of the treatment given to primary sources aim exactly to promote a debate on how to overcome the disjunction between historical methodology and the topics of international relations in handling the history of the Brazilian foreign policy.

\section{The fragmentary nature of sources and its consequences}

According to Finley (1994: 39-40), the scarcity and the fragmentary nature of the sources are the most important in a series of issues which the historian of antiquity faces. This implies that the documents left behind by the civilisations the author is studying have diverse origins, various purposes and even completely different material means. More than that, it is unusual to have access to similar sources in an appropriate number in order to understand them satisfactorily. 
Finley identifies, in this source scarcity scenario, a tendency to abhor the gaps, that is, an attempt to establish an interconnection between events, although inadequately supported by the few available sources. The historian - in whose judgment this interconnection should naturally reside - in an attempt to build a comprehensible narrative, fills the gaps with assumptions, which will only be legitimate if they are based on other sources and if their speculative nature is explicitly stated (Finley 1989: 65, 1994, 14-16; Bloch 1952: 40; Carr 1990: 28).

The MRE keeps millions of documents. A large number of them - although only a fraction of the whole - have been available for at least three decades (See Ministry of Foreign Relations [Brazil] 2018). Archive research depended on precarious rules which created large gaps in the availability of documents. It has become commonplace for a large part of studies on foreign policy to be carried out based on the public statements of Brazilian authorities, comments from the press, or documents made available by the MRE itself.

In studies on the history of Brazilian foreign policy towards Israel, such as those by Breda dos Santos (2000) and Vigevani and Kleinas (2000), the association of available elements in order to add consistency to the narrative is evident. This implies an attempt to infer from the incomplete documentation, which deals with sparse episodes, a general meaning that cannot necessarily be based on the sources in a systematic manner. Even in the studies which draw most on theoretical frameworks in the field of foreign policy in general, such as Spektor (2006: 198-199, for example, dealing with the Middle East), inferences are made which, however plausible, are not substantiated by sources, but make the narrative intelligible.

A relatively common strategy, highlighted by Momigliano (1950:287) is the grouping of information in chronological parataxis, the mere placing of historical sources one after another, without indication of co-ordination or subordination, as the antiquarians used to do, leading to what is more of a chronicle than a history, as Barreto (2012: 451-468) does in dealing with the Middle East.

In another example, Caraciki (2013) reflects on the motivations and objectives of the Brazilian vote in favour of Resolution 3379 (UNGA1975d). When studies on the topic are mentioned, it is notable how what underlies his critique is the problem of the scarcity of sources, as is the suggestion of links of causality in spite of insufficient data. Caraciki (2013: 127) refers especially to the works of Breda dos Santos (2000) and Lessa (2000), which 'share the same explanation for the vote: the attempt by the Brazilian diplomacy to ensure the supply of oil for the national industry in the 1970s,' but which 'diverge when it comes to the Itamaraty's intents [...]. Breda dos Santos, he notes, considered that the vote had been the result of oil constraints, which led Brazil to steer away from Israel. For Lessa the vote had been 'strictly economic', 'an expression of Brazilian universalism' in the face of the 'isolation of radical occidentalism' that shaped Brazilian relations, frequently aligned with US political decisions, before the Geisel administration.' Lessa, Caraciki remarks, 'runs into what I see as an excessive rationality with regard to the decision-making process in foreign policy, reifying concepts formulated by the Brazilian diplomacy in order to justify its actions as absolute indicators.' 
The Yom Kippur War (1973), the boycott by oil-producing Arab nations and the enormous Brazilian dependency on oil imports, in view of the large emphasis given by the Geisel administration to diversifying and modernising the national industry, are in fact a combination of factors that created a great vulnerability for Brazil. The explanation that the Brazilian decision to vote in favour of the resolution stemmed from Brazil's interest in oil is probably more representative of the historiography. Symptomatically, those who adopt it generally refer to the resolution in the context of considerations on the entirety of the foreign policy or on the policy towards the Middle East as a whole. Usually, there are succinct references to Brazilian interests in Arab oil or to the need to keep up the pace of development of the 'Miracle' (for example, Gonçalves and Myiamoto 1993: 233). It remains that, in spite of these constraints, no sources are mentioned that support this rationale in a solid and systematic way.

Many of the references do not make it explicit whether Brazil sought to get closer to the Arab nations in order to avoid inclusion in a new list of oil sale embargoes (Voigt 2010: 164) or whether it wanted to attract investments in petrodollars (Toscano 2010: 85). Different studies point in different directions, but most seem to remain ambiguous. Lampreia (2010: 50-52, 173-174), in an interview given in 2008, discusses Brazil having taken 'pro-Arab' stances for fear of cuts in the supply of oil, but does not associate the vote on the resolution on Zionism to this concern.

In no case are reflections made on the working mechanism of the embargo in 1973 and its dismantling in early 1974, or on the dynamics of the global reinvestment of petrodollars. Such explanations cannot cope with the multiple strands that may arise from the basic fact and cannot discredit possible alternative explanations. As pointed out by Finley (1965: 288-290), this is a common problem in ancient history, when, deprived of specific documents, historians turn inferences from general data into specific causality. In the case of Resolution 3379 (UNGA 1975d), the interpretation is made more difficult because it does not explain apparent contradictions. In particular, it does not explain Brazil's absence, on the same day, at the votes on Resolutions 3375 (UNGA 1975b) and 3376 (UNGA 1975c), favourable to Palestinian interests, at the UN General Assembly.

In another traditional interpretation of the Brazilian vote on the resolution, it is a supposed emerging rivalry between Brazil and the USA which would inevitably lead to disagreements. Resolution 3379 (UNGA 1975d) is seen as a manifestation of the Brazilian quest for autonomy, one more episode in the rivalry which resulted from Brazil's attempt to increase its share of autonomy and/or leadership in a world still divided by the Cold War (Hurrell 2014; Lessa 1998). Moniz Bandeira (1989: 217-248) develops a more mechanistic version of this reasoning, in which the 'emerging rivalry' between Brazil and the USA leads both countries to enact a general pattern of disputes. Dávila and Lesser (2012: 229) interpret the role of the vote on Zionism as part of a deliberate strategy of alignment with the Third World and a search for autonomy in relation to the USA, aiming to 'change Brazil's position at the global stage.' What these interpretations have in common with regard to sources is their restricted use. In this case, the abhorrence of gaps with which Finley (1989: 65, 1994: 14-16) deals results in the imposition of a model to make up for the lack of empirical data. 


\section{The predominance of discursive sources and the importance attributed to individual documents}

When the historian is confronted with a lack of sources and a difficulty in establishing context, there is a possible course of action, if not a tendency - to appeal to a history of ideas, that is, to transform the sources, especially the discursive ones, into the object of study itself. In reality, the most complex documents end up being the interpretive key to the rest - even if there is no obvious reason why they should (Finley 1994: 17-20, 1989: 63-64; see also Marrou 1954: 118-119). As Finley (1994: 24) jokingly says, '[...] the narrative is the queen of tradition; without it, much of the other data would be unintelligible.' This implies not only the possibility of using concepts laid out in the sources as analytic instruments - a tendency which Finley perceives in those who study Thucydides - but also the imperceptible abandonment of the external phenomenon (the Trojan War or the Peloponnesian War) in favour of the study of the description an author makes of the subject (Finley 1974).

In the field of the history of Brazilian foreign policy, the tendency to turn the sources, especially the discursive ones, into the very object of study manifests itself in two correlated phenomena which bring more difficulties to the field. First, there is the abundant and sometimes exclusive use of speeches and public declarations on foreign policy as a basis for the study and as the key to the interpretation of any other sources. There is nothing incorrect about the procedure in itself, as long as its limits are recognised, as done by Pilla (2011), in studying Brazil's stance towards the Middle East at the United Nations Security Council.

Second, there is the uncertainty with regard to what exactly Brazilian foreign policy is - whether it is a set of daily acts or what its formulators and executors or analysts say about it or even, which seems more logical, an interrelation between both. As well evinced by Hurrell (2014: 16), foreign policy is related to a set of political, economic and sometimes diplomatic actors and elements. However, the tendency is for the studies on the history of Brazilian foreign policy to take the official discourse on foreign policy not only as a mould or a guide, but also as an adequate reflection of its underlying reality, instrumentalising its labels as elements of analysis. This, however, should not be assumed, but rather demonstrated, lest, to paraphrase Geertz (1973: 448), foreign policy be replaced with a story foreign policy tells itself about itself.

As for the history of Brazilian foreign policy for the Middle East, an example of this is the recurring idea of 'equidistance.' This concept was wielded by former Chancellor Mario Gibson Barboza (2002) as representative of the Brazilian position with regard to the Israeli-Arab conflict between 1947 and 1973. The term has been adopted as a key to

analysing the Brazilian stance until the mid-1970s, and, a contrario sensu, the following period, which would be the end of equidistance.

It is important to underline that the term 'equidistance' does not refer to a strategy for dealing with the Middle East. Its use implies a post facto overvaluation of the region's place within Brazilian foreign policy. It is worth reminding that Azeredo da Silveira directly accused his predecessor of 'inventing' the idea of equidistance on the eve of having 
to 'abandon it' with the oil shock of 1973 (Goldfeld 2004: 100). The idea of equidistance certainly does not reflect a strategy for the region, especially since 'one can properly speak not of a Brazilian policy toward the region, but of a mostly reactive diplomacy, oriented toward immediate interests or the lack thereof' (Breda dos Santos, 2000: 67). Following this line, Casarões and Vigevani (2014: 151-152) try to demonstrate how a large part of the Brazilian foreign policy towards the Middle East can be explained by factors other than Brazil's relations with the nations of the region.

Another aspect that is directly connected to the predominant nature of discursive sources is the fascination with the individual document and a difficulty in comparing it with similar testimonies. On the issue, Finley (1994: 59) comments: '[what] I seek is to take the focus of the attention of research from individual, normally isolated documents to those which can be submitted to collective analysis and, whenever possible, which can be presented in a series within a specific time frame.' Although the passage suggests a procedure for aggregating data, it can be useful for qualitative research. The existence of a set of official documents collected by diplomats and made available to the public before going to institutional archives - for example, the Azeredo da Silveira Archive, opened by the Center for Contemporary Brazilian History Research and Documental Center (CPDOC) - show how the prior selection carried out by the collector can lead to this obstacle.

In the case of the vote on Resolution 3379 (UNGA1975d), the consideration on how to vote produced dozens of diplomatic records at the Brazilian Mission in New York, the Embassy in Tel Aviv, and the Embassy in Washington, not to mention other missions, in addition to a series of reports for the president. Only a small fraction of those documents had been made available, until recently, to historians, who tended to be guided by the available documents, especially the Azeredo da Silveira Archives. Pinheiro (2002: 77-78) warns, very precisely, of the limited use of private archives. The existence of sets of documents produced on the same topic can certainly contribute much to the discussion on the information found on personal files, although any archive will select its documents, with or without explicit criteria (Bloch 1952: 29-30).

Spektor (2006, 2009), for example, through the abundant use of archival sources of the Azeredo da Silveira collection, carried out several studies that noticeably changed the interpretation which had been used until then. In his point of view, the idea of a rivalry did not correspond to the actual relations between the two countries: at the time, Brazil and the USA had been making efforts to build a positive agenda, based on relations that were as symmetrical as possible. Especially with Henry Kissinger representing Washington and Azeredo da Silveira representing Brasília, Brazil had its status as a power recognised by the USA. Due to the strong critical reaction in the USA to the Brazilian vote in favour of a resolution equating Zionism with racism, Brazil's decision had become practically irreversible. This means that, from the Brazilian point of view, backtracking in this case could have thwarted a balanced dialogue with the USA (Breda dos Santos and Uziel 2015 follow this line). Caraciki (2013) - also based on an ample use of sources from the Azeredo da Silveira files - presents a variation on this tendency, in which the vote is depicted as an instrument to leverage Brazil's Third Worldist position in relation to the USA and the Western bloc. 
These interpretations are theoretically and empirically underpinned by much wider bases, but they err in what Finley (1989: 59) called a preponderance of single documents, not set in a series and compared to others so as to produce adequate standards for their analysis (Bloch 1952: 52-53; Marrou 1954: 105-106). The use of the Azeredo da Silveira files does not allow the analyst to cross-check those documents with others produced by Itamaraty at the same time, documents which could have suggested paths other than the one followed by Geisel and Silveira.

\section{The use of oral history as a supplementary source}

Oral history - or rather, the study of oral traditions subsequently recorded in writing - is also a field wherein ancient history has developed research methods which can help the history of Brazilian foreign policy (with the obvious reservation that ancient historians cannot interview the contemporary actors of their object of study).

It is important to highlight that classic historians - such as Finley and Momigliano (particularly Momigliano 1982b) - end up having less frequent experiences with oral traditions. Experts on the ancient Near East - especially those who deal with the Bible as a source - and ethnohistorians are usually more receptive to oral traditions. Before resuming considerations based on Finley, it is important to reemphasise from those Near East and ethno- historians two points: a) oral traditions recorded in written sources can be seen as 'depth-dimensional sources' (More 2006: 34), that is, as stories contained within oral traditions that reveal relevant elements of a past reality or episode; and b) the evaluation of oral traditions and the practice of oral history share theoretical assumptions and interpretive techniques, as well as inherent limitations (Byrskog 2002: 26-33; Vansina 1985: 12-13).

Finley, among Greek and Roman historians, had a particularly strict view on the value of oral tradition, derived from his studies of the Homeric world (Palmeira 2007: 132-140), which led him to question, in the end, the very occurrence of the Trojan War. The main lesson here is the inverse relationship between the acuity of the information and the time elapsed or number of generations transmitting the tradition (Finley, Caskey, Kirk and Page 1964; Finley 1974). In order to bring this assertion closer to the history of Brazilian foreign policy, some points are useful: all memory (individual or collective) acts selectively, whether deliberately or not; memory which is transmitted orally often aims not to record data for practical purposes, but rather - which is very important for diplomacy - to increase the prestige or justify the existence of an institution or practice; the resulting oral tradition appears to be presented at random, and often, when it comes to specific events, modify, confuse, transplant and make up details (Finley 1965: 295-300).

The use of oral history to mitigate some of the difficulties in dealing with the history of Brazilian foreign policy has been gaining momentum with the release by the CPDOC of long interviews granted by diplomats and politicians, especially former Chancellors such as Vasco Leitão da Cunha (1994), Antonio Azeredo da Silveira (Spektor 2010), Ramiro Saraiva Guerreiro (2010), Luiz Felipe Lampreia (2010) and Francisco Rezek (2016). At 
various moments throughout these testimonies, it is notable how the elements described above appear, such as selectivity and the retrospective construction of coherence. Even Guerreiro, known for his impressive memory, and whose interview, cross-checked with archive documents, does not show many contradictions, in the case of Resolution 3379 (UNGA 1975d), tended to present a conflated version, with little room for the comings and goings of the decision-making process (Guerreiro 2010: 222-223).

This is worth illustrating with two examples of the uses and risks of oral history in studying the Brazilian vote on Resolution 3379 (UNGA 1975d). The first: in his long statement to the CPDOC, in 1994, almost 20 years after the event, Geisel (D'Araujo and Castro 1997: 341-342) conveyed the impression of having felt no hesitation whatsoever in favouring the draft resolution. Yet other interlocutors had independently recorded that a change in the vote was seriously considered (Abreu 1979; Góes 1978; Mariz 1993). Furthermore, in an attempt to justify the vote and build a narrative where he had never doubted his decision, Geisel presented arguments of a Volksgeistlich tone with regard to Jews, which was taken by some to be clear proof that the motivation behind the Brazilian vote had been anti-Semitic.

It is important to make a few points as to the issue of anti-Semitism in the history of the Brazilian vote. At the time, in the USA and in Israel, Resolution 3379 (UNGA 1975d) was immediately associated with the anti-Semitism which supposedly predominated in Arab nations and in the USSR, and which would be presented under the guise of anti-Zionism. In Brazil, the same association was soon made, but analysts, perhaps fearful of reprisals, hesitated in branding Brazilian authorities as anti-Semitic. Given that many of the statements on the racist character of the resolution came coupled with criticisms of Chancellor Silveira's statements, it can be assumed that they were, in part, read as insinuations that he had a racist or anti-Semitic stance.

In the Jewish-Brazilian community, the vote in favour of the resolution was seen as a frightening manifestation of anti-Semitism which was all the more notable for occurring almost simultaneously with the assassination of Vladimir Herzog in São Paulo. It led to fears that there would be other acts of an 'anti-Semitic' nature carried out by the government - which turned out to be unjustified (Kleinas 2012; Reichhardt 2015). A manifesto was published, and endorsed by community leaders (See Jornal do Brasil 1975b; Jornal do Brasil 1975d; D’Araújo 1997; Breda dos Santos 2000). The topic of Resolution 3379 (UNGA 1975d) is still relevant to the Jewish-Brazilian community, evoking perceptions of, if not anti-Semitism, at least an anti-Israel posture.

The interpretive chain regarding anti-Semitism is scarcely based on primary sources, especially because the interpretive key is the central element. The main evidence is recollections of the individuals involved, with all the difficulties inherent to oral history, and the public declarations of Brazilian authorities, interpreted in an unsystematic manner within the set of sources. For instance, a paragraph of Brazil's explanation of the vote is brought up that suggests that the Jewish community's loyalty to Brazil is questionable. This paragraph was in fact included by Chancellor Silveira, but a systematic evaluation of the anti-Semitism factor in the entirety of the decision-making process is not carried out 
(UNGA 1975a: 798). Finley's contention for a theoretical framework to deal with scarce evidence is turned on its head, in favour of a narrative so strong that it limits the very interpretation of the sources (Finley 1994: 26). The prior decision on what to look for results in obtaining the necessary facts to prove the proposed hypotheses (Carr 1990: 23).

As to Geisel's statement, Marcos Chor Maio (1999), in a short but highly instructive comment, emphasises how the opinions of the former president evinced a mentality that was common among military personnel and civil servants of his generation - not necessarily an active feeling that led him to a favourable vote regardless of political and diplomatic considerations.

The second example on the uses and risks of oral history in the case of the Brazilian vote on Resolution 3379 (UNGA 1975d): in a 2002 lecture, the Jewish community leader Eliezer Burlá attributed the Brazilian decision to anti-Semitic feelings which had been fostered by Chancellor Azeredo da Silveira, stating that he had known for a fact that the Minister of Foreign Relations had been responsible for the decision (Breda dos Santos 2003: 13). Cross-checking with other sources shows that a memory adjustment is likely to have taken place - Burlá had not had access to Azeredo da Silveira at the time and only met with Geisel after the final vote at the UN (Jornal do Brasil 1975d). Indications are, in general, that Silveira would rather have abstained and that it was Geisel's decision to vote favourably (Spektor 2006; Breda dos Santos and Uziel 2015). Furthermore, it can be speculated that there was an incentive for the 'blame' to be laid on the chancellor, and not on the president, with whom the Jewish leader claims to have been close in the 1970s.

\section{The difficulty in establishing a context for document production}

The last point with regard to primary sources in the study of the history of Brazilian foreign policy, especially when it comes to the MRE's documents, is the difficulty in understanding the context of their production. Here Finley also gives interesting lessons:

The first question to be asked with regard to any document refers to the reason or motive why it was written. This question is not asked often enough, for one unconsciously assumes that the reasons and purposes are self-evident, that is, that they are more or less the same as our own (Finley 1994: 44).

A large part of the documents that make it to the historian's hands, especially when they are not explicitly part of a documental series, are devoid of context, with no clarity when it comes to the intentions of whoever produced it or to the importance of whoever produced it within the decision-making process. In a situation where sources are fragmentary, it is not possible to know whether a document represents the desire of an authority to carry out a certain policy or whether it reflects an existing practice, not to mention the ignorance with regard to how it was received by the interlocutor (Finley 1994: 15, 46; Bloch 1952: 35). 
At the MRE, a decision on how to vote on a draft resolution relative to the Middle East at the United Nations undoubtedly involves an initial communication from the Mission in New York, communications on the topic by embassies in the Middle East and in the major powers, memoranda, and internal information, frequently consultations with other ministries and even the office of the president - which was certainly the case regarding the vote on Resolution 3379 (UNGA 1975d) (Breda dos Santos and Uziel 2015).

Internal archival systems, in addition, make it so that a set of documents cannot always be found in one location (Penna Filho 1999: 132). Even more difficult is that the organ has its own internal dynamics which attributes different values in the decision-making process to documents of various origins, even when this is not clear on the document itself. This is not a fatal problem for research, but one must be aware of the gaps and assess the relative weight of each document in the decision-making process, which is significantly easier if one can follow, documentarily, the path of the decision-making process.

An example might be useful. Soon after the first vote, in the Third Committee, on what would become Resolution 3379 (UNGA 1975d), Chancellor Silveira travelled to Europe to visit London, Paris and Rome. As was practice at the time, a 'Chancellor Series' was established, that is, a special series of communications sent from Brasília to the missions for the Minister to be aware of the facts, and from the missions to Brasília for him to send instructions. Through this mechanism, the relationship between Brasília and the embassy where he was was temporarily inverted. When the decision finally came to vote in favour of the draft, the acting Minister, Ramiro Saraiva Guerreiro, consulted with Silveira by means of a cable in the Chancellor Series sent to Paris on the terms of the instruction to be given to the Mission in New York (Brazil 1975). For those who are not aware of the mechanism, of the context of the decision-making process or of the subtleties of the documentation, it may seem that it was the Ambassador in Paris, Delfim Netto, who had been consulted. This would include an element that does not exist in the decision-making process. Caraciki (2013: 151) effectively makes a similar misstep, attributing authorship of an instruction to the Ambassador in London, Mario Gibson Barboza - who profoundly disagreed with Silveira on Middle East affairs.

Finally, the difficulty in establishing the context of the production of the sources can lead to, as explained by Finley (1989: 39-40), a tendency to quote a previous study as a source, without critiquing the bases in the primary sources for its statements - making the perception of the past, as stated by Carr (1990: 14), predetermined. In the case of Resolution 3379 (UNGA 1975d), the debate on the relationship between oil and the Brazilian vote runs into this bias.

Newspapers at the time stated, almost always criticising the government, that the Brazilian vote had followed 'pragmatic' considerations in order to benefit from the oil-producing Arab nations. There are no indications from government sources which evince this motivation, and the argument seems to derive on the one side from the obvious and growing energy and capital needs, and, on the other, from the political and economic power obtained by the Arab nations, after the oil shock in late 1973. This perspective was absorbed into later academic analyses, especially the pioneering and oft-quoted study by Hartog (1989), which was based on speeches and news regarding visits of Arab 
dignitaries, some of them from months or years prior to the vote (Jornal do Brasil 1975a; O Estado de S. Paulo 1975; Hartog 1989).

This interpretive tendency suggests a relationship of direct causality, not a general context in which the decision was made, between the Brazilian vote and a supposed interest in pleasing the oil producers. However, specific documents - such as the information taken by Chancellor Silveira to President Geisel so as to help make a decision on these votes - make no mention of the issue of oil. Only a very convoluted logic could suggest that oil was such an important topic that it could be completely omitted in discussions and at the same time be the direct cause of the decision.

\section{Conclusion}

The history of Brazilian foreign policy has a privilege which never has been and never will be accorded to ancient history, that is, the ability to count on the release, as the LAI is effectively implemented, of millions of new substantive, narrative sources, serialised in the files of the Brazilian state. This documentary mass could lead to a revolution in the understanding of the history of Brazilian foreign policy. It will undoubtedly raise more questions than will be possible to answer, but the answers it does provide will be able to reverberate more efficiently.

It is fitting to add a few words on how the future might take shape. First, as has already been expressed, any collection of documents contains traps, such as deliberate or casual selection, filing errors, etc. The advantage of great state files is allowing for the analysis of a series of documents, wherein systematic, malicious or random adulteration is less likely. This does not imply that official sources are more precise or 'truer' (Trachtenberg 2006). In any branch of history, all sources must be approached with the same degree of criticism (Bloch 1952: 35).

Additionally, the wave of new documents cannot drown out the necessary discussion on the origins of the interpretations of Brazilian foreign policy phenomena, especially with regard to the role of academia and of the organic intellectuals of Itamaraty, as well as to the value of official discourse as an interpretive source (Fonseca Júnior 2011). This implies critically rethinking the labels given to the various aspects of Brazilian foreign policy, their periodisation, and even the very definition of what foreign policy is.

Finally, one cannot study themes of foreign policy as an isolated phenomenon without contemplating the whole of this governmental policy (Casarões and Vigevani 2014: 151). Finley (1989: 63-64) warns about this tendency to use one process to circumscribe the other without a reason for it. This does mean that one can only study Brazilian foreign policy as long as one also studies all other state policies. What is proposed is actually to avoid starting from the assumption that the processes of foreign policy begin or end at the limits of internal institutional developments.

To quote Finley (1989: 72) one last time: 'professionalism tells the historian what questions to ask, not what answers to give.' Sources allow possible answers to be pointed out. 


\section{Notes}

1 In the field of international relations, rationalists - realists, neorealists, liberals, neoliberals - assume the strategies and preferences of the actors to be rational. Specifically on Brazilian foreign policy, Jesus (2010) developed an interesting critique of the traditional perspectives on international relations, in contrast with the greater explanatory potential of the reflexivistic theories such as constructivism, poststructuralism or postcolonialism.

2 Law No 12.527, from 18 November 2011. Studies indicate that, despite improvements in access to information, LAI implementation by Itamaraty and by the federal public administration need greater progress (Waisbich, Cetra and Marchezini 2017).

3 The thesis of the rivalry between Brazil and the USA by Moniz Bandeira has become widespread in Brazilian historiography, fitting into various themes and periods of the relations between the countries. See Spektor's (2007: 30, note 10) comments.

4 On the concept of the history of ideas, see part IV, 'How things are,' Darnton (1995: 175-225).

5 Going beyond the specific area of the Middle East, it is worth noting that the terminology coined by Chancellor Silveira of 'responsible and ecumenical pragmatism' - nowadays seen as canonical and central to the academic understanding of the phenomenon - was strongly questioned at the time, as well as scorned by the press. See 'Dois Enfoques do Conflito Mundial', O Estado de S. Paulo (1975a).

6 Carr (1990: 18-19), who gave up diplomacy to become a historian, warns exactly about this typical characteristic of archives privately collected by diplomats.

7 The study edited by Mallea, Spektor and Wheeler (2015), dealing with the concept of a 'critical oral history', illustrates the growing caution with the difficulties of using interviews.

8 On this understanding with respect to the resolution, see Manor (1997) and Raeli (1984, 1986).

9 See, for example, in the Jornal do Brasil. 'Sionismo e Racismo' (Leviski 1975) and the editorial of O Estado de S. Paulo (1975b), 'O Problema Árabe-Israelense'. Lafer (1975) published on 16 November in the Jornal do Brasil a sophisticated analysis of Resolution 3379, in which he explains that it was anti-Semitic propaganda, but he did not deal with the Brazilian decision itself.

10 See the speech given by Henry Chmelnitsky (2014), a representative of the Israeli-Brazilian Confederation (CONIB), at the conference 'Diálogos de Política Externa.'

11 Hartog's text with regard to Resolution 3379 (UNGA 1975d) suggests that the device establishing an equivalence between Zionism and racism was part of a wider resolution on fighting racism. This is a factual mistake. Somalia's original proposal was indeed to include devices in an omnibus resolution. This strategy, however, was changed before the vote at the Third Committee (Manor 1997: 14-36).

\section{References}

Abreu, Hugo. 1979. O Outro Lado do Poder. Rio de Janeiro: Nova Fronteira.

Barboza, Mario Gibson. 2002. Na Diplomacia, o Traço Todo da Vida. Rio de Janeiro: Francisco Alves.

Barreto, Fernando de Mello. 2012. A Política Externa após a Redemocratização, vol. 1 (1985-2002). Brasília: Funag.

Bloch, Marc. 1952. Apologie pour l'Histoire ou Métiers d'Historien. Paris: Armand Colin.

Brazil. 1975. 'Secretaria de Estado to Brasemb Paris, 24 October, Cable 90 (Chancellor Series).' Historical Archive of the Itamaraty. 2011. Law No 12.527, 18 November 2011. 2012. Decree No 7.724, 16 May 2012. 
Breda dos Santos, Norma. 2000. 'O Brasil e a questão israelense nas Nações Unidas: da criação do Estado de Israel ao pós(?)-sionismo.' In Norma Breda dos Santos (ed), Brasil e Israel: Diplomacia e Sociedades. Brasília: Editora da UnB, pp. 19-70.

2003. 'As Posições Brasileiras nas Nações Unidas com Relação ao Oriente Médio (19452002): Equidistância, Pragmatismo e Realismo.' Cena Internacional 5 (2): 5-22.

Breda dos Santos, Norma and Eduardo Uziel. 2015. 'Forty Years of the United Nations General Assembly Resolution 3379 (XXX) on Zionism and Racism: The Brazilian Vote as an instance of United States-Brazil Relations.' Revista Brasileira de Política Internacional 58 (2): 80-97.

Brown, Peter. 1988. 'Arnaldo Dante Momigliano 1908-1987'. Proceedings of the British Academy 74: 405-442.

Buzan, Barry and George Lawson. 2016. 'Theory, history, and the global transformation.' International Theory 8 (3): 502-522.

Byrskog, Samuel. 2002. Story as History - History as Story. The Gospel Tradition in the Context of Ancient Oral History. Boston: Brill Academic.

Caraciki, Leonel. 2013. A Aposta Antissionista: a Equação do Sionismo como Racismo na Resolução 3379 da Assembleia Geral das Nações Unidas (1975). Masters dissertation, Universidade Federal do Rio de Janeiro, Brazil.

Cardoso, Ciro Flamarion. 1986. Uma Introdução à História. 5th ed. São Paulo: Brasiliense.

1997. 'História e paradigmas rivais.' In Ciro Flamarion Cardoso and Ronaldo Vainfas (eds), Domínios da História: Ensaios de Teoria e Metodologia. Rio de Janeiro: Campus, pp. 1-23.

Cargill, Jack. 1986. 'A memorial address for Sir Moses Finley.' The Journal of the Rutgers University Libraries 48 (2): 65-74.

Carr, Edward H. 1990. What is History? London: Penguin Books.

Casarões, Guilherme and Tullo Vigevani. 2014. 'O lugar de Israel e da Palestina na política externa brasileira: antissemitismo, voto majoritário ou promotor da paz?’ História 33 (2): 150-188.

Chmelnitsky, Henry. 2014. Speech addressed at the conference 'Diálogos sobre Política Externa,' Ministry of Foreign Affairs of Brazil, 21 March. At http://www.conib.org.br/noticias/2412/discursode-henry-chmelnitsky-vice-presidente-da-conib-na-srie-de-debates-dilogos-sobre-poltica-externa-promovida-pelo-itamaraty [Accessed on 28 December 2018].

Cunha, Vasco T Leitão da. 1994. Diplomacia em Alto-Mar: Depoimento ao CPDOC. Rio de Janeiro: FGV.

D’Araujo, Maria Celina and Celso Castro. 1997. Ernesto Geisel. 3rd ed. Rio de Janeiro: FGV.

Darnton, Robert. 1995. O Beijo de Lamourette. Mídia, Cultura e Revolução. São Paulo: Companhia das Letras.

Dávila, Jerry and Jeffrey Lesser. 2012. 'Brasil, Israel y el voto sionismo-racismo en las Naciones Unidas (1975)'. In Raanan Reim (ed), Más allá del Medio Oriente. Granada: Eirena, pp. 227-241.

Deese, David. 2008. World Trade Politics. Power, Principles and Leadership. Londres: Routledge.

De Jesus, Diego. 2010. 'Alternative analytical axes of Brazilian foreign policy'. International Political Sociology 4: 419-435.

Elman, Colin and Miriam F Elman. 2001. 'Negotiating international history and politics.' In Colin Elman and Miriam F Elman (eds), Bridges and Boundaries: Historians, Political Scientists and the Study of International Relations. Cambridge: MIT Press, pp. 1-83. 
Febvre, Lucien. [1952] 1992. Combats pour l'Histoire. Paris: Armand Colin.

Finley, Moses I. 1965. 'Myth, memory, and history'. History and Theory 4 (3): 281-302.

1974. 'Schliemann's Troy - one hundred years after.' Procedings of the British Academy 60: 393-412.

1989. Uso e Abuso da História. São Paulo: Martins Fontes.

1994. História Antiga. Testemunhos e Modelos. São Paulo: Martins Fontes.

Finley, M I, J L Caskey, G S Kirk and D L Page. 1964. 'The Trojan War.' The Journal of Hellenic Studies 84: 1-20.

Fonseca Júnior, Gelson. 2011. Diplomacia e Academia. Um estudo sobre as Análises Acadêmicas sobre a Política Externa Brasileira na Década de 70 e sobre as Relações entre o Itamaraty e a Comunidade Acadêmica. Brasília: FUNAG.

Gaddis, John L. 1987. 'Expanding the data base: Historians, political scientists, and the enrichment of security studies.' International Security 12 (1): 3-21.

1997. 'History, theory and common ground.' International Security 22 (1): 75-85.

Geertz, Clifford. 1973. The Interpretation of Cultures. Nova York: Basic Books.

Góes, Walder de. 1978. Brasil do General Geisel: Estudo do Processo de Tomada de Decisão no Regime Militar-Burocrático. Rio de Janeiro: Nova Fronteira.

Goldfeld, Monique S. 2004. O Fim da Equidistância: o Veto Brasileiro ao Sionismo e a Política Externa do Governo Geisel para o Oriente Médio (1974-1979). Masters dissertation, Universidade Estadual do Rio de Janeiro, Brazil.

Gonçalves, Williams and Shiguenoli Myiamoto. 1993. 'Os militares na política externa brasileira: 1964-1984.' Estudos Históricos 6 (12): 211-246.

Guerreiro, Ramiro Saraiva. 2010. Ramiro Saraiva Guerreiro (Depoimento, 1985). Rio de Janeiro: CPDOC.

Fundação Getúlio Vargas [online]. Guia dos Arquivos do CPDOC. At https://cpdoc.fgv.br/acervo/ arquivospessoais/guia http://cpdoc.fgv.br/acervo/arquivospessoais/guia[Accessed on 2 June 2016].

Hartog, Carlos A M den. 1989. 'O Brasil e o Oriente Médio.' In Sérgio França Danese (ed), Ensaios de História Diplomática do Brasil (1930-1986). Brasília: IPRI, Fundação Alexandre de Gusmão, pp. 143-152.

Hobson, John M and George Lawson. 2008. 'What is history in international relations?' Millennium: Journal of International Studies 37 (2): 415-435.

Hopkins, Keith and Moses Finley. 2014. 'Keith Hopkins interviews Sir Moses Finley.' American Journal of Philology 135 (2): 179-201.

Hurrell, Andrew. 2014. The Quest for Autonomy. The Evolution of Brazil's Role in the International System, 1964-1985. Brasília: FUNAG.

Jervis, Robert. 2001. 'International history and international politics: Why are they studied differently?' In Colin Elman and Miriam F Elman (eds), Bridges and Boundaries: Historians, Political Scientists and the Study of International Relations. Cambridge: MIT Press, pp. 385-402.

Jew, Daniel, Robin Osborne and Michael Scott. 2016. M. I. Finley. Cambridge: Cambridge University Press.

Jornal do Brasil. 1975a. 'Eqüidistância e pragmatismo'. 22 October. 
1975b. 'Racismo na ONU.' 2 November.

1975c. 'Vitória do racismo.' 12 November.

1975d. 'Presidente recebe líderes e assegura respeito a judeus.' 2 December.

Kleinas, Alberto. 2012. A Morte de Vladimir Herzog e a Luta Contra a Ditadura: A Desconstrução do Suicídio. Masters dissertation, Universidade Federal de São Carlos, Brazil.

Lafer, Celso. 1975. 'A ONU, Israel e o sionismo' Jornal do Brasil, 16 November. At http://memoria. bn.br/DocReader/DocReader.aspx?bib=030015_09\&PagFis=131335 [Accessed on 20 June 2016].

Lampreia, Luiz Felipe. 2010. Luiz Felipe Lampreia (Depoimento, 2008). Rio de Janeiro: CPDOC.

Larson, Deborah L. 2001. 'Sources and methods in Cold War history: The need for a new theory-based archival approach.' In Colin Elman and Miriam F Elman (eds), Bridges and Boundaries: Historians, Political Scientists and the Study of International Relations. Cambridge: MIT Press, pp. 111-135.

Lessa, Antonio C. 1998. 'A diplomacia universalista do Brasil: a construção do sistema contemporâneo de relações bilaterais.' Revista Brasileira de Política Internacional 41 (special issue): 29-41.

Levy, Jack S. 2001. 'Explaining events and developing theories: History, political science, and the analysis of international relations.' In Colin Elman and Miriam F Elman (eds), Bridges and Boundaries: Historians, Political Scientists and the Study of International Relations. Cambridge: MIT Press, pp. 39-83.

Leviski, Fernando. 1975. 'Sionismo e Racismo.' Jornal do Brasil, 4 November. At http://memoria. bn.br/DocReader/DocReader.aspx?bib=030015_09\&PagFis=130692 [Accessed on 20 June 2016].

Maio, Marcos Chor. 1999. 'Qual anti-semitismo? Relativizando a questão judaica nos anos 30' In Dulce Pandolfi (ed), Repensando o Estado Novo. Rio de Janeiro: FGV, pp. 229-256.

Mallea, Rodrigo, Matias Spektor and Nicholas Wheeler. 2015. The Origins of Nuclear Cooperation. A Critical Oral History between Argentina and Brazil. Rio de Janeiro/Washington: FGV/Wilson Center. Manor, Yohanan. 1997. To Right a Wrong. The Revocation of the UN General Assembly Resolution 3379 Defaming Zionism. Nova York: Shengold Publishers.

Marichal, Robert. 1961. 'La critique des textes.' In Charles Samaran (ed), L'Histoire et ses Méthodes. Paris: Gallimard, pp. 1247-1360.

Mariz, Vasco. 1993. 'O Oriente Médio hoje e amanhã.' Defesa Nacional 762.

Marrou, Henri-Irénée. 1954. De la Connaissance Historique. Paris: Seuil.

Ministry of Foreign Relations [Brazil]. n.d. Citizen Information Service (SIC). http://www.itamaraty. gov.br/pt-BR/servico-de-informacao-ao-cidadao-sic. At http://www.itamaraty.gov.br/pt-BR/servico-de-informacao-ao-cidadao-sic [Accessed on 4 November 2018].

Momigliano, Arnaldo. 1950. Ancient history and the antiquarian, Journal of the Warburg and Courtauld Institutes 13 (3/4): 285-315.

1975. 'The Greeks and us.' New York Review of Books, 16 October.

1982a. 'Introduction: histoire ancienne et histoire.' Annales. Économies, Sociétés, Civilisations 37 (5): 687-696.

1982b. 'Biblical studies and classical studies: Simple reflections about historical method.' The Biblical Archeologist 45 (4): 224-228. 
2003. 'História antiga e história.' In François Hartog (edited by José Otávio Guimarães), Os Antigos, o Passado e o Presente. Brasília: EdunB, pp. 189-204.

Moniz Bandeira, Luiz Alberto. 1989. Brasil-Estados Unidos: A rivalidade emergente (1950-1988). Rio de Janeiro: Civilização Brasileira.

More, Megan Bishop. 2006. Philosophy and Practice in Writing a History of Ancient Israel. Norfolk: Biddles Ltd.

Morris, Ian. 1999. 'Foreword to updated edition.' In M. Finley, The Ancient Economy. Berkeley: University of California Press.

O Estado de S. Paulo. 1975a. 'Dois enfoques do conflito mundial', 22 October.

. 1975b. 'O problema árabe-israelense', 2 November.

1975c. 'Um voto difícil de entender,' 21 October.

Owens, Patricia. 2016. 'International historical what?' International Theory 8 (3): 448-457.

Palmeira, Miguel S. 2007. Moses Finley e a 'Economia Antiga': a Produção Social de uma Inovação Historiográfica. $\mathrm{PhD}$ thesis, Universidade de São Paulo, Brazil.

Penna Filho, Pio. 1999. 'A pesquisa histórica no Itamaraty'. Revista Brasileira de Política Internacional 42 (2): $117-144$.

Pilla, Bruno. 2011. O posicionamento do Brasil sobre o Oriente Médio no Conselho de Segurança das Nações Unidas (1993-2005). Masters dissertation, Universidade Federal do Rio Grande do Sul, Brazil.

Pinheiro, Letícia. 2002. 'O Pragmatismo Responsável no Arquivo do Presidente Geisel.' In Celso Castro and Maria Celina D’Araujo (eds), Dossiê Geisel. Rio de Janeiro: FGV.

2013. Foreign Policy Decision Making under the Geisel Government. Brasília: FUNAG.

Raeli, Ruth. 1984. The Steps that Led to the United Nations General Assembly 3379. Jerusalem: World Zionist Organization.

1986. The Implications of Resolution 3379 on Zionism. Jerusalem: World Zionist Organization.

Reichhardt, David Creimer. 2015. A Multidão Silenciosa: Vladimir Herzog, Assassinado. Etnografia de um Evento. Masters dissertation, Universidade Estadual de Campinas, Brazil.

Rezek, José Francisco. 2016. José Francisco Rezek (Depoimento, 2014), Vol 2. Rio de Janeiro: CPDOC/ FGV.

Salomón, Mónica and Letícia Pinheiro. 2013. 'Análise de política externa e política externa brasileira: trajetória, desafios e possibilidades de um campo de estudos.' Revista Brasileira de Política Internacional 56 (1): 40-59

Schroeder, Paul W. 1997. 'History and international relations theory: Not use or abuse, but fit or misfit.' International Security 22 (1): 64-74.

Spektor, Matias. 2006. Equivocal Engagement: Kissinger, Silveira, and the Politics of U.S.-Brazil Relations (1969-1983). PhD thesis, Oxford University, UK. 2009. Kissinger e o Brasil. Rio de Janeiro: Zahar. (ed). 2010. Azeredo da Silveira: um Depoimento. Rio de Janeiro: FGV.

Steiner, Zara. 1997. 'On writing international history: Chaps, maps and much more.' International Affairs 73 (3): 531-546. 
Toscano, Daniella M B. 2010. A Influência do Sistema Petrobras sobre a Ação Externa do Governo de Ernest Geisel (1974-1979). Curitiba: Juruá.

Towbridge, H Ford. 1972. 'Towards a better relation between history and political science.' Government and Opposition 7 (2): 207-228.

Trachtenberg, M. 2006. The Craft of International History: a Guide to Method. Princeton: Princeton University Press.

United Nations General Assembly (UNGA). 1975a. Thirtieth Sessions, Official Records, A/PV.2400. New York.

. 1975b. Resolution 3375, A/RES/3375(XXX). New York. 1975c. Resolution 3376, A/RES/3376 (XXX). New York. 1975d. Resolution 3379, A/RES/3375(XXX). New York.

Vainfas, Ronaldo. 1997. 'Caminhos e descaminhos da história.' In Ciro Flamarion Cardoso and Ronaldo Vainfas (eds), Domínios da História: Ensaios de Teoria e Metodologia. 5th ed. Rio de Janeiro: Campus, pp. 441-449.

Vansina, Jan. 1985. Oral Tradition as History. Madison: The University of Wisconsin Press.

Vigevani, Tullo and Alberto Kleinas. 2000. 'Brasil-Israel: da partilha da Palestina ao reconhecimento diplomático.' In Norma Breda dos Santos (ed), Brasil e Israel: Diplomacia e Sociedades. Brasília: Editora Universidade de Brasília, pp. 71-113.

Vigezzi, Brunello. 2000. “Teóricos” e "historiadores” das Relações Internacionais.' In J B Duroselle (ed), Todo Império Perecerá: Teoria das Relações Internacionais, Brasília/São Paulo: Editora Universidade de Brasília/Imprensa Oficial do Estado.

Vlassopoulos, Kostas. 2007. Unthinking the Greek Polis. Ancient Greek History beyond Eurocentrism. Cambridge: Cambridge University Press.

Voigt, Márcio Roberto. 2010. O Impacto dos Choques Petrolíferos na Diplomacia Brasileira (19691985). PhD thesis, Universidade Federal do Rio Grande do Sul, Brazil.

Waisbich, Laura Trajber, Raísa Cetra and Joara Marchezini. 2017. 'The transparency frontier in Brazilian foreign policy'. Contexto Internacional 39 (1): 179-200.

Wendt, Alexander. 1998. 'On constitution and causation in international relations.' Review of International Studies 24: 101-117.

\section{Acknowledgments}

The opinions and arguments expressed here are those of the authors and do not necessarily reflect those of Brazil's Ministry of Foreign Affairs.

\section{About the authors}

Eduardo Uziel is a Brazilian diplomat. He was posted to the Mission of Brazil to the UN (2006-2009), to the Brazilian Embassy in Tel Aviv (2009-2012) and to the Mission of Brazil to the EU (2016-present). He was Professor of International Organizations in the Instituto Rio Branco (Brazilian diplomatic academy). He is currently a $\mathrm{PhD}$ candidate in political science at the Université Libre de Bruxelles, studying the absence of Brazil 
from the Security Council from 1969 to 1987. He has published the book O Conselho de Segurança, as Missões de Paz e o Brasil no Mecanismo de Segurança Coletiva das Nações Unidas (Brasília, FUNAG, 2015) and several articles on United Nations peacekeeping and Security Council affairs.

Norma Breda dos Santos is Associate Professor in the Institute of International Relations at the University of Brasília. She holds a PhD in Political Science (International Relations) from the Institut universitaire de hautes études internationales, Geneva, and an MA in Law from the Federal University of Santa Catarina. Her areas of main interest are the history of international relations, the history of Brazilian foreign policy, the multilateral dimension of Brazilian foreign policy and the history of Brazilian relations with the Middle East countries.

\section{Crítica da Fonte e a História da Política Externa Brasileira}

Resumo: O presente artigo trata da metodologia histórica no campo da política externa brasileira a partir de reflexões sobre o tratamento de fontes primárias e as lições de dois importantes historiadores da Antiguidade: Moses I. Finley e Arnaldo Momigliano. Sem desprezar as diferenças de temporalidade implicadas, entende-se que é possível aproximar e estabelecer um respeitoso diálogo entre a história contemporânea e a história antiga. $\mathrm{O}$ artigo apresenta primeiramente uma discussão preliminar sobre as fontes para a história da política externa brasileira, seguida de uma série de análises e comentários sobre diversos aspectos do tratamento de fontes primárias: a) o caráter fragmentário das fontes e suas consequências; b) a predominância de fontes discursivas e a importância atribuída aos documentos individuais; c) o uso da história oral como fonte; d) a dificuldade em estabelecer o contexto da produção do documento. São utilizados trabalhos relativos à política externa brasileira para o Oriente Médio, em especial o caso do controverso voto favorável do Brasil à Resolução 3379 (XXX) da Assembleia Geral das Nações Unidas, em 1975, que equiparou o sionismo ao racismo, escolha que deriva do caráter controverso do voto brasileiro e da própria Resolução.

Palavras-chave: política externa; metodologia; relações internacionais; história da política externa brasileira; história internacional.

Received on 2 March 2018, and approved for publication on 2 October 2018.

\section{(cc) BY-NC} https://creativecommons.org/licenses/by-nc/4.0/ 
